\title{
On the occurrence and distribution of Presbytis comata (Desmarest, 1822) (Mammalia: Primates: Cercopithecidae) in Java, Indonesia
}

\author{
Vincent Nijman \\ Institute for Systematics and Population Biology (Zoological Museum), University of Amsterdam, \\ P.O. Box 94766, 1090 GT Amsterdam, The Netherlands
}

Keywords: Cercopithecidae, Indonesia, Java, Presbytis comata, Presbytis fredericae, primates

\begin{abstract}
The colobine monkey Presbytis comata is confined to the rain forests of West and Central Java, Indonesia. In order to determine its distribution, a review of the literature, evidence from the study of museum specimens, and the results of recent surveys are presented. Recent surveys in the central parts of the island indicate that $P$. comata is still present on four volcanic mountain complexes, viz. Mt. Sawal, Mt. Slamet, Mts. Dieng, and Mt. Lawu. The present paper gives the results of the surveys combined with a review of its distribution. Altitudinal and habitat preferences, and the conservation status of the species are discussed.
\end{abstract}

\section{Zusammenfassung}

Die Verbreitung des Slankaffen Presbytis comata ist beschränkt auf die Urwälder West- und Zentraljavas, Indonesien. Um seine Verbreitung festzustellen werden eine Literaturübersicht, eine Untersuchung von Museumsexemplaren und die Resultate neuer Feldstudien wiedergegeben. Demnach kommt $P$. comata noch immer auf vier verschiedenen Vulkangruppen vor: Sawal, Slamet, Dieng und Lawu. Dieser Artikel kombiniert die Ergebnisse der Feldstudien mit einer Übersicht aller bekannten Verbreitungsvorkommen und diskutiert Höhe- und Habitatpräferenzen sowie die jetzt notwendigen Schutzmassnamen.

\section{Introduction}

Indonesia supports a relatively high number of colobine monkeys belonging to the genus Presbytis sensu stricto and, due to the partial isolation of Asia and the intermittent connection between islands, the country includes numerous endemic taxa. One of these is the Grizzled leaf monkey
Presbytis comata (Desmarest, 1822) [formerly $P$. aygula, see Weitzel \& Groves, 1985], endemic to the island of Java, viz., the West and Central Javan provinces. Animals of this species live in single male groups containing three to over thirteen individuals. During the day the troops frequently visit the middle and lower layer of the forest, whilst resting at night in the upper layer (Ruhiyat, 1983). The species is stricktly arboreal and is restricted to rain forest areas with a continuous forest canopy. Presbytis comata plays an important ecological role as one of the principal arboreal shoot- and leaf-eating mammals of the Javan rain forest, although fruit may also be eaten when available (Sujatnika, 1992; Ruhiyat, 1983; 1991). Little is known about the ecology of the species, and particularly knowledge about its distribution at the individual and population level is limited (Supriatna et al., 1994).

Java is Indonesia's most cultivated large island and has a long history of forest conversion and degradation. Nowadays less than $10 \%$ of the original forest remains in Java and especially West and Central Java have suffered from deforestation. In these two provinces $48 \%$ of the montane forest, $14 \%$ of the hill forest and less than $2 \%$ of the lowland forest remains (MacKinnon et al., 1982). For the latest update on land use and ecological issues concerning the island of Java (and Bali), see Whitten et al. (1996).

Because of its small, fragmented populations and its severely reduced habitat Presbytis comata is considered to be among the most endangered primate species in the world (Eudey, 1987). 
$P$. comata -together with another Javan endemic, the Javan gibbon Hylobates moloch (Audebert, 1799)- have suffered more than any other Malaysian primate from deforestation (MacKinnon, 1987). Population size estimates have been theoretically calculated and range from 8040 (MacKinnon, 1987) to 2285 (Supriatna et al., 1994).

Sody (1930) described the subspecies $P$. $c$. fredericae based on specimens collected on the southern slopes of Mt. Slamet, Central Java. This subspecies differs from the grizzled nominate from West Java in having a dark collar on the upper side of the chest and a dark belly region, and by the occurrence of melanistic individuals. A more elaborate discussion on geographical variation in pelage characteristics in $P$. comata is discussed elsewhere (Nijman, in press). Otherwise very little has been written about the occurrence of $P$. comata in Central Java. If mentioned at all, the species was most frequently reported to occur on or to the east of Mt. Slamet (Chasen, 1940; Hooijer, 1962; Medway, 1970; MacKinnon, 1987; Weitzel et al., 1988; Ruhiyat, 1991; Corbet \& Hill, 1992). Apart from Kappeler (1984), who conducted a gibbon survey in 1978 and visited some sites in Central Java, and $\mathbf{M}$. Linsley (pers. comm, 1994), few people have extended or concentrated their (biological) surveys into Central Java (see e.g. Appendices II and III in Whitten et al., 1996). Eudey (1987) states that $P$. c. fredericae is known with certainty only from Mt. Slamet. However, Bartels (1937) reported the occurrence of the species on the northwestern slopes of the Dieng mountains, and moreover some specimens have been collected on the Dieng mountains and Mt. Lawu, on the border between Central and East Java (National Museum of Natural History (hereafter RMNH), Leiden, coll. Bartels, no. 14612, 14613, and 14614).

The only other record from the eastern half of the island comes from Eugène Dubois who collected a fragment of the right palate with P3-M2 in situ of a Presbytis sensu stricto from a Middle Pleistocene deposit in Sumber Kepuh $\left(112^{\circ} 5^{\prime} \mathrm{E}\right.$, $7^{\circ} 30^{\prime} \mathrm{S}$ ), East Java (RMNH, coll. Dubois, no. 3780). The sediments in which the fossils were found are of volcanic origin and Dubois inferred that the animals in the deposits died due to a volcanic eruption. Based on the structure of the sediments he concluded that most likely this had been an eruption of Mt. Wilis (cf. Theunissen, 1985).

The aim of the present paper is to synthesize the main results from studies published in various journals and unpublished reports, not all of which are easily accessible, and to integrate this with new data on the distribution and conservation status of central Javan populations of $P$. comata, collected during two field surveys in 1994 and 1995. An overview of the historic and present distribution of $P$. comata is given, after which new data on the species gathered in the central parts of Java are presented. Finally, altitudinal and habitat preferences are discussed, and some recommendations for conservation are given.

\section{Methods}

\section{Study sites}

In order to assess the current distribution of $P$. comata in the central parts of Java, data were gathered over an eight months (March-Sept.) period during 1994, with an additional two months (June-July) survey in 1995. Surveys were conducted in almost all forest areas larger than 5000 ha, between east of Mt. Papandayan and Mts. Wilis-Liman. The forest areas visited included Mt. Sawal, Mt. Segara, Mt. Slamet, Mts. Dieng, Mt. Sundoro, Mt. Sumbing, Mt. Merapi, Mt. Muria, Mt. Lawu, and Mts. Wilis-Liman (see Table I). Together the forests on these mountains comprise more than $90 \%$ of the remaining natural forest in the central part of the island.

In the same period additional data on the distribution of the species were collected on Mt. Pancar and Mt. Gede-Pangrango, both in West Java.

\section{Survey methods}

The area was surveyed by scanning the forest area from vantage points over the canopy and by surveys inside the forest along available trails. Data were collected on habitat type and order of disturbance, and when the species was detected, notes on group size, age-class composition, habitat utilization, altitude, and behaviour were taken. Additional data on the presence or absence of $P$. comata were gathered by semistructured interviews with local people living in the vicinity of the forests and with officers of nature conservation and forestry departments.

Comprehensive information on the distribution of the species was obtained from the study of specimens in the Museum 
Table I. Study sites on the island of Java, Indonesia.

\begin{tabular}{lllll}
\hline Locality & Status $^{1}$ & Coordinates E-S $^{\prime}$ & Forest type $^{2}$ & Alt. range $^{3}$ \\
\hline Mt. Pancar & unp. & $106^{\circ} 54^{\prime}-6^{\circ} 35^{\prime}$ & wet hill & $700-1000$ \\
Mt. Gede-Pangrango & NP & $107^{\circ} 00^{\prime}-6^{\circ} 45^{\prime}$ & wet hill-montane & $800-3019$ \\
Mt. Sawal & wr & $108^{\circ} 16^{\prime}-7^{\circ} 12^{\prime}$ & wet hill-montane & $700-1764$ \\
Mt. Segara & {$[\mathrm{nr}] /$ unp. } & $108^{\circ} 48^{\prime}-7^{\circ} 07^{\prime}$ & wet lowland-submontane & $300-1812$ \\
Mt. Slamet & {$[\mathrm{nr}]$} & $109^{\circ} 15^{\prime}-7^{\circ} 15^{\prime}$ & wet hill-montane & $700-3000$ \\
Mts. Dieng & {$[\mathrm{wr}] /$ unp. } & $109^{\circ} 37^{\prime}-7^{\circ} 05^{\prime}$ & wet lowland-montane & $250-2565$ \\
Mt. Sundoro & pf & $110^{\circ} 00^{\prime}-7^{\circ} 17^{\prime}$ & wet montane & $2000-3135$ \\
Mt. Sumbing & {$[\mathrm{nr}]$} & $110^{\circ} 04^{\prime}-7^{\circ} 22^{\prime}$ & wet lowland-montane & $500-3371$ \\
Mt. Merapi & {$[\mathrm{rf}]$} & $110^{\circ} 26^{\prime}-7^{\circ} 32^{\prime}$ & wet montane & $900^{\prime}-2911$ \\
Mt. Muria & {$[\mathrm{nr}]$} & $110^{\circ} 52^{\prime}-6^{\circ} 37^{\prime}$ & moist hill-submontane & $600-1620$ \\
Mt. Lawu & {$[\mathrm{nr}]$} & $111^{\circ} 11^{\prime}-7^{\circ} 40^{\prime}$ & wet submontane-montane & $1000-3000$ \\
Mt. Wilis-Liman & {$[\mathrm{wr}]$} & $111^{\circ} 46^{\prime}-7^{\circ} 48^{\prime}$ & moist-wet hill-montane & $600-2563$ \\
\hline
\end{tabular}

${ }^{\prime} \mathrm{NP}=$ national park (Taman Nasional), $\mathrm{nr}=$ nature reserve (cagar alam), $\mathrm{pf}=$ protection forest (hutan lindung), $\mathrm{ff}=$ recreation forest (hutan wisata), unp. $=$ unprotected, $w r=$ wildlife reserve (suaka margasatwa), [ ] = proposed. ${ }^{2}$ After MacKinnon et al., $1982 .{ }^{3}$ Numbers in italic represent approximate lower and upper limits of forest; abefore the eruption on 22-11-1994: present state of forest unknown but lower limit has gone up considerably and only the eastern slopes are left covered with natural forest (Rudiyanto, pers. comm., 1996).

Zoologi (Bogor, MZB), the British Museum of Natural History (London, BMNH) and the National Museum of Natural History (Leiden, RMNH), from the literature, and from unpublished data obtained by correspondents.

\section{Results}

\section{Geographic distribution}

Map 1 and Table II show the localities where $P$. comata has been recorded, both in historic and recent times. The species' distribution encompasses the area from the westernmost tip of the island at Ujung Kulon to Mt. Lawu on the border between Central and East Java. It has been recorded in 33 forest patches, most of which are located in the West Javan province and a few records originate from the Central Javan province. The only records from East Java are those from Mt. Lawu and the Middle Pleistocene fossil excavated at Sumber Kepuh.

\section{Distribution in the central parts of Java}

In this section, information gathered in the central parts of the island are discussed in a west to east sequence.
Mt. Sawal: The characteristic vocalizations of $P$. comata were recorded in a secondary forest patch, on the southern slopes at $1025 \mathrm{~m}$. The dense cover prevented sightings of the animals although the group was very close at hand. Three other individuals and a juvenile were seen later resting in an emergent tree in the primary forest at an altitude of $935 \mathrm{~m}$.

According to local villagers and staff from the forestry department, $P$. comata is also present in the higher parts on the northern slopes, although the species was not recorded there.

Mt. Slamet: Both in 1994 and 1995, groups of $P$. comata were recorded on several occasions on the southern slopes near the hotwater springs near 'Pancuran tujuh', north of the village of Baturaden. Group sizes ranged from $4-5$ to 10 individuals and records were established at altitudes between 700 and $910 \mathrm{~m}$.

On 30 June 1995, the vocalizations of $P$. comata were heard coming from the edge of the forest at $1985 \mathrm{~m}$, on the eastern slopes of Mt. Slamet. The same day two other groups were observed. The first group consisted of more than three individuals and was seen descending to a lower part of the mountain from an altitude of $2150 \mathrm{~m}$. A few moments later a group of Ebony leaf monkeys, Trachypithecus auratus (E. Geof- 
Table II. Localities with records, and altitude (in $\mathrm{m}$ above sea level) when available, of Presbytis comata, forest type with its approximate present altitudinal range, and climate type.

\begin{tabular}{|c|c|c|c|c|c|c|}
\hline No.* & Locality & $\begin{array}{l}\text { Coordinates } \\
\text { E-S }\end{array}$ & $\begin{array}{l}\text { Forest } \\
\text { type*** }\end{array}$ & $\begin{array}{l}\text { Alt. range } \\
\text { forest }^{\dagger}\end{array}$ & $\begin{array}{l}\text { Climate } \\
\text { type }^{\dagger t}\end{array}$ & $\begin{array}{l}\text { Alt. record } \\
{\text { (reference })^{\text {tht }}}^{\text {to }}\end{array}$ \\
\hline 1. & Ujung Kulon & $105^{\circ} 20^{\prime}-6^{\circ} 45^{\prime}$ & $\mathrm{L}$ & $0-623$ & $2-3$ & $0-200(1-2)$ \\
\hline 2. & Cerita & $105^{\circ} 50^{\prime}-6^{\circ} 10^{\prime}$ & L & 100 & 2 & (3) \\
\hline 3. & Ranca Danau & $106^{\circ} 00^{\prime}-6^{\circ} 10^{\prime}$ & $\mathrm{L}$ & $90-744$ & 3 & $(3-4)$ \\
\hline 4. & Haurbentes-Jasinga & $106^{\circ} 27^{\prime}-6^{\circ} 31^{\prime}$ & $\mathbf{P}$ & $200-470$ & 3 & $200-470(5)$ \\
\hline 5. & Cikepuh/Cibanteng & $106^{\circ} 25^{\prime}-7^{\circ} 12^{\prime}$ & L & $0-235$ & 2 & (6) \\
\hline 6. & Halimun & $106^{\circ} 30^{\prime}-6^{\circ} 40^{\prime}$ & H/SM/M & $500-1929$ & 3 & $\begin{array}{l}\text { (4), 700-1075 (7), } \\
900-1200(6)\end{array}$ \\
\hline 7. & Pelabuhan Ratu & $106^{\circ} 32^{\prime}-6^{\circ} 59^{\prime}$ & L & 100 & 2 & $30(8)$ \\
\hline 8. & Mt. Salak & $106^{\circ} 45^{\prime}-6^{\circ} 45^{\prime}$ & $\mathrm{SM} / \mathrm{M}$ & $1700-2211$ & 3 & 600 (a) \\
\hline 9. & Jampang & $106^{\circ} 47^{\prime}-7^{\circ} 15^{\prime}$ & - & - & $2-3$ & (b) \\
\hline 10. & Mt. Pancar & $106^{\circ} 54^{\prime}-6^{\circ} 35^{\prime}$ & $\mathrm{H}$ & $700-1000$ & 3 & $785-850(9)$ \\
\hline 11. & Mt. Gede-Pangrango & $107^{\circ} 00^{\prime}-6^{\circ} 45^{\prime}$ & $\mathrm{H} / \mathrm{SM} / \mathbf{M}$ & $800-3019$ & 3 & $\begin{array}{l}900-1400(9) \\
1000-2600(5)\end{array}$ \\
\hline 12. & Ciwangi & $107^{\circ} 02^{\prime}-7^{\circ} 04^{\prime}$ & - & - & 3 & $1200(8)$ \\
\hline 13. & Sanggabuana & $107^{\circ} 15^{\prime}-6^{\circ} 35^{\prime}$ & L/H & $150-1219$ & 2 & (6) \\
\hline 14. & Mt. Magesit & $107^{\circ} 20^{\prime}-7^{\circ} 05^{\prime}$ & $\mathrm{SM} / \mathrm{M}$ & $1000-2078$ & 3 & (10) \\
\hline 15. & Kamojang & $107^{\circ} 22^{\prime}-7^{\circ} 10^{\prime}$ & $\mathbf{M}$ & $1400-2250$ & 3 & $1390-1625(11)$ \\
\hline 16. & Mt. Simpang & $107^{\circ} 25^{\prime}-7^{\circ} 15^{\prime}$ & $\mathrm{H} / \mathrm{SM}$ & $600-1600$ & 3 & (10) \\
\hline 17. & Mt. Tilu & $107^{\circ} 30^{\prime}-7^{\circ} 09^{\prime}$ & SM/M & $1200-2177$ & 3 & $(4-10-11)$ \\
\hline 18. & Burangrang & $107^{\circ} 33^{\prime}-6^{\circ} 46^{\prime}$ & SM/M & $1000-2000$ & $2-3$ & (6) \\
\hline 19. & Cibeureum & $107^{\circ} 33^{\prime}-7^{\circ} 10^{\prime}$ & - & - & 3 & (c) \\
\hline 20. & Mt. Kencana & $107^{\circ} 35^{\prime}-7^{\circ} 18^{\prime}$ & $\mathrm{H} / \mathrm{SM} / \mathrm{M}$ & $600-2182$ & 3 & (10) \\
\hline 21. & Mt. Papandayan & $107^{\circ} 45^{\prime}-7^{\circ} 20^{\prime}$ & $\mathrm{SM} / \mathrm{M}$ & $1000-2622$ & 3 & (11) \\
\hline 22. & Patenggang & $107^{\circ} 46^{\prime}-7^{\circ} 08^{\prime}$ & $\mathbf{M}$ & $1600-1775$ & 3 & $1600-1775(11)$ \\
\hline 23. & Cikajang & $107^{\circ} 47^{\prime}-7^{\circ} 22^{\prime}$ & - & - & 3 & 900 (d) \\
\hline 24. & Mt. Limbung & $107^{\circ} 50^{\prime}-7^{\circ} 25^{\prime}$ & L/H/SM & $300-1815$ & 3 & (10) \\
\hline 25. & Magesit Kareumbi & $107^{\circ} 54^{\prime}-6^{\circ} 54^{\prime}$ & H/SM & - & $2-3$ & (6) \\
\hline 26. & Mt. Sawal & $108^{\circ} 16^{\prime}-7^{\circ} 12^{\prime}$ & $\mathrm{H} / \mathrm{SM}$ & $700-1764$ & 3 & 915-1025 (9) \\
\hline 27. & Mt. Ciremay & $108^{\circ} 25^{\prime}-7^{\circ} 00^{\prime}$ & $\mathrm{SM} / \mathrm{M}$ & $1000-3078$ & 3 & (12) \\
\hline 28. & Ciringin & $108^{\circ} 30^{\prime}-7^{\circ} 27^{\prime}$ & - & - & 3 & (e) \\
\hline 29. & Mt. Slamet & $109^{\circ} 15^{\prime}-7^{\circ} 15^{\prime}$ & $\mathrm{H} / \mathrm{SM} / \mathrm{M}$ & $700-3000$ & 3 & $\begin{array}{l}1000(\mathrm{f}), 1400(\mathrm{~g}) \\
1500(13), 700-2350(9)\end{array}$ \\
\hline 30. & Mt. Cupu/Simembut & $109^{\circ} 26^{\prime}-7^{\circ} 14^{\prime}$ & L/H & $350-1000$ & 3 & $350-1000(14)$ \\
\hline 31. & Mt. Lumping & $109^{\circ} 38^{\prime}-7^{\circ} 07^{\prime}$ & L/H/SM & $250-1327$ & 3 & $300-1300(9)$ \\
\hline 32. & Mt. Prahu & $109^{\circ} 55^{\prime}-7^{\circ} 10^{\prime}$ & $\mathbf{M}$ & $1600-2565$ & 3 & $\begin{array}{l}1300-1400(15) \\
2500-2565(9)\end{array}$ \\
\hline 33. & Mt. Lawu & $111^{\circ} 11^{\prime}-7^{\circ} 40^{\prime}$ & $\mathrm{SM} / \mathrm{M}$ & $1000-3000$ & 2 & $\begin{array}{l}1500-1600(\mathrm{~h}), 1880(9) \\
1900(3)\end{array}$ \\
\hline 34. & Sumber Kepuh & $112^{\circ} 05^{\prime}-7^{\circ} 30^{\prime}$ & - & - & 1 (Mt. Wilis 2-3) & (i) \\
\hline
\end{tabular}

* Cf. Map 1.

** $L=$ lowland forest $(0-500 \mathrm{~m}) ; \mathrm{H}=$ hill forest $(500-1000 \mathrm{~m}) ; \mathrm{SM}=$ submontane forest $(1000-1500 \mathrm{~m}) ; \mathrm{M}=\mathrm{montane}$ forest ( $1500 \mathrm{~m}$ and above); $\mathrm{P}=$ forest plantation.

Italic numbers represent approximate altitudes in $\mathrm{m}$ above sea level (after MacKinnon et al., 1982; Kappeler, 1984; pers. observation).

\#t Climate types based on the number of rainy days during the four driest consecutive months of the year (abbreviated as RDFDCM): 1 = areas with 0-10 RDFDCM; 2 = areas with 10-30 RDFDCM; 3 = areas with more than 30 RDFDCM (after Van Steenis, 1965).

ttt Key: (1) Hoogerwerf, 1970; (2) Gurmaya et al., 1992; (3) S. van Balen, pers. comm., 1995; (4) Van der Zon, 1979; (5) Sujatnika, 1992; (6) Supriatna et al., 1994; (7) Kool, 1992; (8) Napier, 1985; (9) present study; (10) MacKinnon et al., 1982; (11) Ruhiyat, 1991; (12) Weitzel et al., 1988; (13) Seitre \& Seitre, 1990; (14) Linsley \& Nawimar, 1994, in Brandon-Jones, 1995; (15) Bartels, 1937; (a) RMNH 34302/34336/34337/34338; (b) MZB 3817; (c) RMNH 26822; (d) MZB 6646; (e) RMNH 34296; (f) RMNH 34318; (g) MZB 167; (h) RMNH 14614; (i) Middle Pleistocene fossil, coll. Dubois no. 3780, RMNH. 


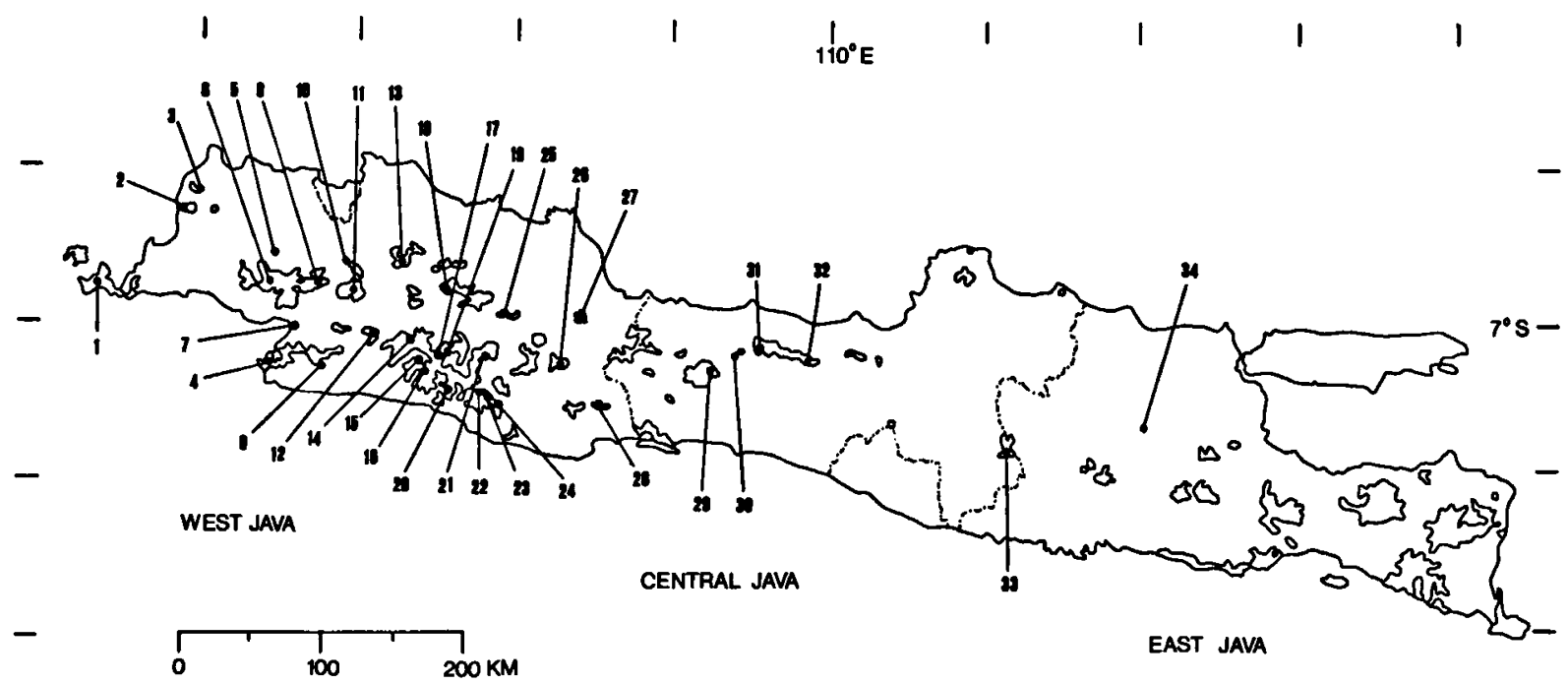

Map 1. Geographical distribution of Presbytis comata in Java, Indonesia. The map shows areas covered with natural forests, excluding mangrove and swamp forest (after RePPProT, 1990), and the localities where $P$. comata has been recorded. Numbers correspond with those listed in Table II.

froy, 1812), were seen heading in the same direction. It is not clear whether the two species formed one group or were divided into two separate groups. A mixed group of both species was observed later that day: a group of 9 leaf monkeys -3 to 4 of which $P$. comata - were seen moving in the upper layer of the canopy, in oaklaurel forest at an altitude of $2350 \mathrm{~m}$.

Mts. Dieng: $P$. comata was found in different parts of this c. $255 \mathrm{~km}^{2}$ large forest block, ranging from lowland to upper-montane. The species was first seen on 5 June 1994, near the summit (2565 $\mathrm{m})$ of Mt. Prahu in the easternmost part. Two individuals were moving through the upper strata of the forest, and one could be observed for up to half an hour (Nijman \& Sözer, 1995). Near this observation point, in June 1995, a group of leaf monkeys was observed but it was not clear whether or not $P$. comata was involved.

In the lower parts near the village of Linggo, seven times a group was seen ranging from 3 to 13 individuals and two groups were detected by means of their vocalizations only. Records were established at altitudes of $1300 \mathrm{~m}$ on Mt. Lumping to $650 \mathrm{~m}$ near Linggo, but the species was also reported to occur at the lower parts to $\mathrm{c}$. $300 \mathrm{~m}$.
Mt. Lawu: The species was recorded once during five days of surveying, in the montane forests $(1880 \mathrm{~m})$ between Cemoro Sewu and the waterfall of Mojosemi near Sarangan, East Java. On 12 July 1995, the characteristic diagnostic vocalizations of $P$. comata were heard and a few minutes later a group of at least seven leaf monkeys was observed. Although the light conditions were far from optimal due to the incoming darkness, the shape of the monkeys and the clear presence of a pale belly and underside of tail left no doubt that $P$. comata was involved. Groups of Ebony leaf monkeys were also observed in the area.

According to local informants, two types of budeng (East Javan name for Ebony leaf monkey) were present. I have not spoken with anybody who was familiar with the name (lutung) rekrakan (Javanese name for $P$. comata), nor have I heard of anyone who had a local word to describe the species other than budeng or lutung (the latter name is used in West and Central Java and Bali to indicate Ebony leaf monkeys).

On 8 October 1988, S. van Balen (pers. comm., 1995 ) recorded a group of $P$. comata consisting of 10-15 individuals, at c. $1900 \mathrm{~m}$ in the forests above Cemoro Sewu.

Mt. Wilis: Nowadays only the southeastern 
slopes of Mt. Wilis are left covered with rain forests and might provide a suitable habitat for $P$. comata. The remainder of this mountain complex consists of disturbed secondary forest, bushland and some patches of primary forest. The species was not recorded to be present.

In May 1994, Linsley \& Nawimar (in BrandonJones, 1995) observed P. comata on Mt. CupuMt. Simembut in a fragment of natural forest apparently totally surrounded by pine plantations or open ground. In none of the other forest areas of Central Java has $P$. comata been recorded, nor did we receive information that could indicate its presence.

\section{Discussion}

\section{Geographic distribution}

The present study shows that the distribution of $P$. comata shows a very scattered pattern with records originating from 33 forest areas. In some of these areas the species is only known with certainty from historic observations and whether or not the species is still present in these localities remains to be solved. $P$. comata is a strictly arboreal species and even relatively small areas without forest will not be crossed. The populations in most of the forest areas are thus isolated from one another. Furthermore, within the forested areas the forest proper is often not continuous, resulting in the fragmentation into sub-populations of $P$. comata with a limited or unknown possibility of migration. Surveys in the central parts of Java revealed that $P$. comata is still present in all three localities where it has been reported formerly. The independent observations of $P$. comata on Mt. Lawu by two observers might be significant, as Brandon-Jones (1995) questions the validity of Mt. Lawu as the site of collection for the skin collected by Bartels (RMNH 14614). Fact is that Bartels did collect on Mt. Lawu (see e.g. photographs in Becking, 1989), and whether or not this skin was indeed collected on Mt. Lawu or on the Mts. Dieng, as suggested by Brandon-Jones (1995), might be of historic interest only.

At present it is unlikely that, apart from the
Mts. Pembarisan-Mt. Segara and perhaps some small isolated forest patches, the species will be present at any other locality. Mts. Pembarisan is an area of lowland and hill forest probably over $200 \mathrm{~km}^{2}$ of which c. $130 \mathrm{~km}^{2}$ are proposed as conservation forest (MacKinnon, 1987) where both Javan gibbon and Ebony leaf monkey were observed (Nijman \& Sözer, 1995). Most of the forests in Central Java are severely diminished, and almost all remaining forest areas were visited for several days.

In some areas, for instance Mt. Sundoro and Mt. Sumbing, the absence of $P$. comata may simply be explained by the total lack of suitable habitat, i.e., the total absence of closed canopy forest. In other areas the absence is more difficult to explain. Some areas seemed, at least from the human observer's eye, to contain suitable habitat. Most of the forests on the central Javan mountains are rather disturbed, either as a result of human influences and/or of natural causes. Those areas that seem suitable at present may consist of regrowth, while isolation did not allow them to be colonized.

It was not until 1990, when Seitre \&. Seitre (1990) observed $P$. comata on Mt. Slamet, that there was any certainty about the continued existence of the species in Central Java. $P$. comata was also reported to occur on Mt. Slamet by $\mathbf{M}$. Linsley (pers. comm., 1994). The present study shows that the scant information we have on the eastern half of the species' distribution is equally likely due to the limited amount of focussed research done in the area as well as to the rarety of the species. However, it must be stressed that the species is present at few localities only and the nature of the species evades easy observation. Furthermore, for unexperienced observers melanistic individuals are easily confused with the more common Ebony leaf monkey.

With the observations of $P$. comata at $\mathrm{Mt}$. Sawal, the (historic) presence on Mt. Ciremay and at Cisaga, and the present observations at $\mathrm{Mt}$. Slamet, Mts. Dieng, and Mt. Lawu, it becomes clear that the species shows a more or less continuous, though very scattered, distribution from Ujung Kulon in the west to Mt. Lawu in the east. 


\section{Altitudinal distribution}

Some confusion exists in literature about the altitudinal distribution of $P$. comata. Older researchers (e.g. Hoogerwerf, 1970; Medway, 1970) consider the species to be restricted to the lowlands and not to high mountainous regions, and also MacKinnon (1987) restricts the species to the lowland and hill forest up to $1500 \mathrm{~m}$ altitude. According to Whitten et al. (1996) the species' altitudinal limit is probably about $1250 \mathrm{~m}$, although it is sometimes found higher than this, particularly where lowland forests have diminished in area. The given altitudes at which museum specimens were collected range from sea level to $1600 \mathrm{~m}$.

Recent workers (e.g. Ruhiyat, 1983, 1991; Supriatna et al., 1994) however, consider the species to be confined to higher elevations between 1200 and $1800 \mathrm{~m}$, and according to Supriatna et al. (1994), individuals have rarely been noted below $1200 \mathrm{~m}$.

In Table II the approximate present-day altitudinal range of the forest on the different localities is given, as well as altitudes at which individuals have been reported, in present or historic times. From these data it becomes clear that the species covers the whole range between lowland and mountains from sea level up to above 2500 $\mathrm{m}$. As in West and Central Java more than twice as much forest remains above the $1000 \mathrm{~m}$ line than below (MacKinnon et al., 1982), it is possible that the species nowadays is more easily observed in montane areas than in lowland and hill forests.

In some forest areas densities may be very low and the lack of sightings prevents any density estimates from being made (e.g., Ujung Kulon: Hoogerwerf, 1970; Gurmaya et al., 1992; Halimun: Kool, 1992). Calculated densities range from 28 individuals per $\mathrm{km}^{2}$ at altitudes between 650-850 $\mathrm{m}$ on Mts. Dieng (Nijman \& Van Balen, unpublished data), 4-5 per $\mathrm{km}^{2}$ between 900 $1200 \mathrm{~m}$ in Halimun (Maitar in Supriatna et al., 1994), 25 per $\mathrm{km}^{2}$ at $1300-1500 \mathrm{~m}$ on Mt. Gede (Sujatnika, 1992; Sujatnika, pers. comm., 1995), and 11 per $\mathrm{km}^{2}$ at $1400-1600 \mathrm{~m}$ at Kamojang to 35 per $\mathrm{km}^{2}$ at elevations between $1600-1800 \mathrm{~m}$ in
Patenggang (Ruhiyat, 1983). As the primary production of the forest decreases with increasing altitude, and the forest composition changes as well, densities at higher altitudes may be lower when compared with lower altitudes. The only two dietary studies on the species (Ruhiyat, 1983; Sujatnika, 1992) have been conducted in montane forests above $1300 \mathrm{~m}$. Only $8 \%$ (Sujatnika, 1992) and $14 \%$ (Ruhiyat, 1983) of its diet consisted of fruit and seeds, while $45-65 \%$ is more typical for other species of the genus. However, all of these other species have been studied in lowland forests (reviewed by Bennett \& Davies, 1994). Whether these findings are indicative for living in a suboptimal habitat and whether or not the species is 'forced' to live in mountain forests, due to the ongoing deforestation and disturbance in the lowlands, remains to be solved.

\section{Habitat preferences}

Recently $P$. comata has been recorded in both primary and secondary forest, as well as in some plantations (Seitre \& Seitre, 1990; Sujatnika, 1992). According to Supriatna et al. (1994) the species might prefer younger rather than mature forest stands, though the present study indicates that the species is present in both primary and secondary forest habitats. Most likely the optimal habitat for the species will be rather undisturbed primary forest; the incidental observations of $P$. comata in degraded forests or even plantations may not lead to the conclusion that the species can survive in these habitats for a long period of time. The plantation where Seitre \& Seitre (1990) observed the species was situated adjacent to relatively undisturbed natural forest (pers. observation), while the population in HaurbentesJasinga studied by Sujatnika (1992) most likely has been 'trapped' inside the plantation forest, unable to move out as there is no adjacent forest left (Sujatnika, pers. comm., 1995).

The original forest cover in Java consisted of two types: rain forest in the west and monsoon forest in the east (Van Steenis, 1965), Central Java forming the transition zone between the two. The wettest forest types, viz. the mixed lowland 
and hill rain forest and the montane everwet forest occur only in those areas with at least 30 rainy days during the four driest consecutive months of the year (Van Steenis, 1972). On the southern and southwestern slopes of some of the higher mountains in the otherwise seasonally dry East Java, some patches of everwet rain forest exist. Condensation at higher altitudes causes rain to be given off by the otherwise dry south-east trade winds, resulting in 'wet islands' (Van Steenis, 1972). The distribution pattern of mixed lowland and hill rain forest and the montane everwet forest corresponds roughly with the distribution of $P$. comata, with the vast majority of records originating from the wettest areas (see Table II). The forests on Mt. Lawu lie far inside the drought area and the population of $P$. comata on this mountain is postulated to be a relic of a formerly larger distribution.

\section{Conservation status}

Although the range of $P$. comata appears to be more extensive than formerly suggested, the species should still be considered as among the world's most endangered primate species. As discussed above, the species distribution is severely fragmented and it is likely that many populations in the smaller areas contain too few animals to be viable. In the western part of its range at least some of the larger populations occur in relatively safe nature reserves or national parks, most notably Ujung Kulon, Halimun, and Gede-Pangrango. Although populations in these areas are not totally safeguarded from loss of habitat, or occasional poaching or killing, at least there is a chance that these populations may survive in the long term.

This is in contrast with the larger populations in the eastern part of the species' range, all of which are found in unprotected forest, protected forest in water catchment areas, or production forest. None of the forest areas on Mt. Slamet, Mts. Dieng, and Mt. Lawu are protected as conservation forests, although all three areas have been recommended as such (MacKinnon et al., 1982; RePPProT, 1990).

Although more data on the status of $P$. comata are needed, especially for those populations in the central part of the island, some recommendations for its preservation can be given.

In order to get a better insight in the population status of $P$. comata it is suggested to perform a comprehensive survey on the distribution of the species. As little is known about the ecology of the species (cf. Supriatna et al., 1994), more detailed studies could be focussed on the species' habitat preferences and its ability to adapt to various degrees of disturbance over the widest possible range of habitats, in different stadia of re- and degeneration. A dietary study in a lowland forest area, e.g. Mts. Dieng, can explain whether the difference between the reported diets of $P$. coma$t a$ and other members of the genus are intraspecific or due to the fact that $P$. comata has been studied in mountain areas and the others in lowland forests.

As conversion of natural forest, forest fragmentation and encroachment are an ongoing process, raising the status of one or preferably more of the above-mentioned Central Javan forest areas to a higher conservation status, e.g. wildlife reserve, nature reserve, or even national park, seems of prime importance for the survival of the eastern populations of $P$. comata. On the basis of the extent of forest and the number of endemic (bird) species present, the two most important forest areas for conservation are considered to be those on Mt. Slamet and Mts. Dieng (Nijman \& Sözer, 1996). As Java is one of the world's most active volcanic areas and Mt. Slamet is an active volcano, for the long-term preservation of $P$. comata protection of the population on Mts. Dieng seems most feasible. By following the recommendations of MacKinnon et al. (1982), with the extension into the lowland zone as proposed by Nijman \& Sözer (1996), not only $P$. comata would benefit from such an action but also several equally unique and endangered wildlife species, most notably the Javan gibbon and the Javan hawk-eagle Spizaetus bartelsi Stresemann, 1924. 


\section{Acknowledgements}

I would like to thank the Indonesian Institute for Science (LIPI) for their sponsorship and the Directorate General of Forest Protection (PHPA) for allowing me to conduct the fieldwork. Mr. Boeadi (Museum Zoologi, Bogor), Miss P. Jenkins (British Museum of Natural History, London), and Dr. C. Smeenk (National Museum of Natural History, Leiden) are acknowledged for access to specimens under their care, and Dr. J. de Vos (National Museum of Natural History, Leiden) for providing information on the Middle Pleistocene fossil. Resit Sözer and Bas van Balen are thanked for their work during surveys. Constructive comments were made by Dr. P.J.H. van Bree, Dr. J. Chapman, Dr. C.J. Hazevoet, S. Cooper, and Dr. H. Albrecht when reviewing earlier versions of the manuscript and also two reviewers made helpful comments.

\section{References}

Bartels, M., 1937. Zur Kenntnis der Verbreitung und der Lebensweise Javanischer Säugetiere. Treubia, 16: 149164.

Becking, J.H., 1989. Henri Jacob Victor Sody (1892-1959). His live and work. A biographical and bibliographical study: i-viii, 1-272 (Brill, Leiden).

Bennett, E.L. \& A.G. Davies, 1994. The ecology of Asian colobines. In: A.G. Davies \& J.F. Oates (eds.), Colobine monkeys: their ecology, behaviour and evolution: 129171 (Cambridge University Press, Cambridge).

Brandon-Jones, D., 1995. Presbytis fredericae (Sody, 1930), an endangered colobine species endemic to Central Java, Indonesia. Primate Conserv., 16: 68-70.

Chasen, F.N., 1940. A handlist of Malaysian mammals. Bull. Raffles Mus., 15: 1-209.

Corbet, G.B. \& J.E. Hill, 1992. The mammals of the Indomalayan region: a systematic review: 1-488 (Natural History Museum Publications / Oxford University Press, Oxford).

Eudey, A. A., 1987. Action plan for Asian primate conservation: 1987-1991: 1-65 (IUCN/SSC Primate Specialist Group, Gland).

Gurmaya, K.J., A.B. Saryatiman, S.N. Danardono, T.T.H. Sibuea \& I.M.W. Adiputra, 1992. A preliminary study on ecology and conservation of the Java primates in Ujung Kulon national park, West Java, Indonesia: 1-6 (unpublished report, Dept. Biology, Padjadjaran University, Bandung).

Hoogerwerf, A., 1970. Udjung Kulon, the land of the last Javan Rhinoceros, with local and general data on the most important faunal species and their preservation in Indonesia: i-xii, 1-512, pls. I-III (Brill, Leiden).

Hooijer, D.A., 1962. Quaternary langurs and macaques from the Malay archipelago. Zool. Verh. Leiden, 55: 1-64.

Kappeler, M., 1984. The gibbon in Java. In: L. Preuschoft, D.J. Chivers, W.Y. Brockelman \& N. Creel (eds.), The lesser apes: evolutionary and behavioural biology: 19-31 (Edinburgh University Press, Edinburgh).

Kool, K.M., 1992. The status of endangered primates in Gunung Halimun reserve, Indonesia. Oryx, 26: 29-33.

MacKinnon, J., F. Smiet \& M.B. Artha, 1982. A national conservation plan for Indonesia, Vol. III. Java and Bali: iiii, 1-140 (FAO, Bogor).

MacKinnon, K., 1987. Conservation status of primates in Malaysia with special reference to Indonesia. Primate Conserv., 8: 175-183.

Medway, Lord, 1970. The monkeys of Sundaland, ecology and systematics of the cercopithecids of a humid equatorial environment. In: J.R. Napier \& P.H. Napier (eds.), Old World monkeys, evolution, systematics and behavior: 513-553 (Academic Press, New York / London).

Napier, P.H., 1985. Catalogue of primates in the British Museum (Natural History) and elsewere in the British Isles. Part III: Family Cercopithecidae, subfamily Colobinae: 1111 (British Museum (Natural History), London).

Nijman, V., in press. Geographical variation in pelage characteristics in Presbytis comata (Desmarest 1822) (Mammalia: Primates: Cercopithecidae). Z. Säugetierk.

Nijman, V. \& R. Sözer, 1995. Recent observations of the Grizzled leaf monkey Presbytis comata and an extension of the range of the Javan gibbon Hylobates moloch in Central Jawa. Trop. Biodiversity, 3: 45-48.

Nijman, V. \& R. Sözer, 1996. Konservasi Elang Jawa dan jenis-jenis burung endemik Jawa lainnya: Daerah prioritas kawasan konservasi di Jawa Tengah / Conservation of the Javan Hawk-eagle and other endemic bird species on Java: Priority areas for protection in Central Java: Technical Memorandum, 11: 1-8 (PHPA/BirdLife International-Indonesia Programme, Bogor).

RePPProT, 1990. The land resources of Indonesia: a national overview from the regional and physical planning program for transmigration: plates I-XIV (Land Resources Department, National Institute Overseas Development Administration \& Directorat Bina Program, Directorat Penyiapan Pemukiman, Departmen Transmigrasi, London \& Jakarta).

Ruhiyat, Y., 1983. Socio-ecological study of Presbytis aygula in West Java. Primates, 24: 344-359.

Ruhiyat, Y., 1991. Observations of Presbytis aygula in two localities of Java. Comp. Primat. Monogr., 3: 149-191 (Kyoto Univ., Kyoto).

Seitre, R. \& J. Seitre, 1990. Recent sightings of rare primates on Java. Primate Conserv., 11: 18.

Sody, H.J.V., 1930. Pithecus aygula fredericae n. subsp. Tropische Natuur, 19: 68.

Steenis, C.G.G.J. van, 1965. Concise plant-geography of Java. In: C.A. Backer \& R.C. Bakhuizen van den Brink (eds.) Flora of Java, 2: 1-72 (Wolters Noordhoff, Groningen).

Steenis, C.G.G.J. van, 1972. The mountain flora of Java: iviii, 1-147 (Brill, Leiden).

Sujatnika, 1992. Studi habitat Surili (Presbytis aygula Linnaeus, 1758) dan pola penggunaanya di Taman Nasional 
Gunung Gede-Pangrango dan kawasan hutan HaurbentesJasinga: i-xiii, 1-150 (unpublished M. Sci. thesis, Institut Pertanian Bogor).

Supriatna, J., R. Tilson, K.J. Gurmaya, J. Manansang, W. Wardojo, A. Sriyanto, A. Teare, K. Castle \& U. Seal, 1994. Javan gibbon and Javan langur population and habitat viability analysis: i-vi, 1-102 (Report of the Captive Breeding Specialist Group Species Survival Commission of the IUCN; Taman Safari Indonesia, Cisarua).

Theunissen, B., 1985. Eugène Dubois and the ape-man of Java: a contribution to the history of paleoantropology [in Dutch with English summary]: 1-301 (Ph.D. thesis, Univ. Utrecht).

Weitzel, V. \& C.P. Groves, 1985. The nomenclature and taxonomy of the colobine monkeys of Java. Int. J. Primat., 6: 399-409.
Weitzel, V., C.M. Yang \& C.P. Groves, 1988. A catalogue of primates in the Singapore Zoological Reference Collection, Department of Zoology, National University of Singapore (formerly the Zoological Collection of the Raffles Museum). Raffles Bull. Zool., 36: i-iii, 1-166.

Whitten, T., R.E. Soeriaatmadja \& S.A. Afiff, 1996. The ecology of Java and Bali: i-xxiii, 1-969, pls. I-XXXII (Periplus Editions, Singapore).

Zon, A.P.M van der, 1979. Mammals of Indonesia: 1-152 (FO/INS/78/061 Special report UNDP FAO National Park Development Project, Bogor).

Received: 27 March 1996 